\title{
Effect of Fertilization on Soil Properties under Different Poplar Species in Nursery under Temperate Conditions of Kashmir
}

\author{
T.A. Rather, S.A. Gangoo, M.A. Islam*, P.A. Sofi, G.M. Bhat and A.A. Mir \\ Faculty of Forestry, Sher-e- Kashmir University of Agricultural Sciences and Technology of \\ Kashmir, Benhama, Ganderbal-191201, India \\ *Corresponding author
}

\begin{tabular}{|l|}
\hline K e y w o r d s \\
Poplar, Fertilization, \\
nursery, $P$. nigra, $P$. \\
ciliata, $P$. alba, $P$. \\
balsamifera, \\
Kashmir
\end{tabular}

A B S T R A C T
The study investigated the effect of fertilization on soil properties under different poplar species in nursery condition in Kashmir. The experiment was laid out in split plot design (SPT) in nursery beds of $\left(3.60 \mathrm{~m}^{2}\right)$ at spacing of $(60 \mathrm{~cm} \mathrm{x} 30 \mathrm{~cm})$ with 36 treatments, four poplar species (Populus nigra, P. Ciliata, P. alba and P. balsamifera), three levels of $\mathrm{N}$ $\left(\mathrm{N}_{0}, \mathrm{~N}_{75}, \mathrm{~N}_{150} \mathrm{~kg}^{-1}\right)$ and three levels of $\mathrm{P}\left(\mathrm{P}_{0}, \mathrm{P}_{60}, \mathrm{P}_{120} \mathrm{~kg}^{-1}\right)$ replicated three times. The results indicated that the chemical constituents of soil decreased in first year from initial values in respect of $\mathrm{pH}, \mathrm{N}, \mathrm{P}, \mathrm{K}, \mathrm{Ca}$ and $\mathrm{Mg}$ but increased subsequently in second year except $\mathrm{pH}$. The average available soil $\mathrm{N}, \mathrm{P}, \mathrm{K}, \mathrm{Ca}$ and $\mathrm{Mg}$ was recorded maximum at $\mathrm{T}_{9}$ $\left(379.73,383.51 \mathrm{~kg} \mathrm{ha}^{-1}\right),\left(20.53,21.68 \mathrm{~kg} \mathrm{ha}^{-1}\right),\left(219.61,220.90 \mathrm{~kg} \mathrm{ha}^{-1}\right),(845.88,850.08$ $\mathrm{ppm})$ and $262.87,263.56) \mathrm{ppm}$ followed by $\mathrm{T}_{8}$ and $\mathrm{T}_{6}$ but lowest at $\mathrm{T}_{1}(373.00,374.48 \mathrm{~kg}$ $\left.\mathrm{ha}^{-1}\right),\left(18.62,19.09 \mathrm{~kg} \mathrm{ha}^{-1}\right),\left(217.09,218.37 \mathrm{~kg} \mathrm{ha}^{-1}\right),(835.81,840.45 \mathrm{ppm})$ and $(258.32$, $258.93 \mathrm{ppm})$, respectively. Among the species mean maximum decrease in first year from initial values and increase in second year in respect of $\mathrm{N}, \mathrm{P}, \mathrm{K}, \mathrm{Ca}$ and $\mathrm{Mg}$ was recorded in $P$. balsamifera followed by $P$. nigra, $P$. ciliata and $P$. alba in both years, respectively. Hence, $\mathrm{T}_{9}\left(379.73,383.51 \mathrm{~kg} \mathrm{ha}^{-1}\right)$ has been recommended as the best treatment for ETPs production of $P$. nigra, $P$. ciliata, $P$. alba and $P$. balsamifera through cuttings in nursery with regard to soil improvement in Kashmir.

\section{Introduction}

Poplars occupy a unique and important position in the rural economy of North India (Kaushik et al., 2012; Singh and Mavi, 2016). Poplar wood is white in colour having suitable density with an even texture, easy to saw and work, good carving quality indices and finishing quality (Bhardwaj et al., 2001). They are known for their fast growth, easy vegetative propagation, capability to enrich surface soil by adding leaf litter and the ability to provide substantial production 10 to $30 \mathrm{~m}^{3} / \mathrm{ha} / \mathrm{yr}$ on a short rotation of 6 to 12 years (Tewari, 1993). Poplars are grown as a cash crop generating employment in rural areas, raw material for wood based industries, revenue through taxation for the state government as well as meeting the objectives of National Forest Policy, 1988 and rehabilitation of river banks for their protection and averting soil erosion (Islam, 
2016). Due to increasing demand for its wood, Poplar culture is likely to expand within the RIPC and also to new locations in northeastern states along the Himalayan range for the benefit of the people and the country (Dhiman, 2012).

Raising nursery plants of poplars through stem cuttings facilitate multiplication of superior genotypes which is an ultimate option for the cultivation of the species on large scale, thereby enhancing forest productivity (Masoodi et al., 2014; Gangoo et al., 2015). The ability of cutting to root and their subsequent growth in nursery is determined by a number of factors viz., time at which cuttings are taken, age of the donor trees, position within the crown where cuttings are taken, treatment and status of rooting/growth regulators and condition under which cuttings are rooted (Puri,1993; Sofi et al., 2018). $P$. deltoides, $P$. nigra, $P$. balsamifera, $P$. ciliata and $P$. alba are the major poplar species cultivated mostly in Kashmir valley (Rather et al., 2017). Among these poplars, $P$. balsimifera, $P$. ciliata, and $P$. alba are the indigenous species of the valley while $P$. deltoides has been introduced in the valley in 1950 which is cultivated and spread to every nook and corner of the valley due to its fast growth and adaptability (Rather et al., 2018). Various clones of this species have been introduced into the valley but no record is available in the scientific journals. $P$. nigra is said to have been introduced by Mughal's during $18^{\text {th }}$ century as an avenue tree. Now-a-days it is found along National highways and roads as an avenue tree and on boundaries of farmlands as an agro-forestry tree throughout Kashmir valley (Islam et al., 2016). In an investigation (Gangoo et al., 2011), carried out to screen promising clones of $P$. nigra significant inter-clonal variation has been found for various growth characters among the clones of $P$. nigra cultivated in various districts of Kashmir valley. The cultivation of these species is diminishing day by day due to non-availability of information of their management practices and quality plant material (Kumar and Singh, 2012; Sofi et al., 2016). For poplar growing as in case of all the plant species propagated through nursery raised seedlings healthy and vigours nursery plants are a prerequisite (Islam et al., 2015). The proper nutrition provided at nursery stage is of paramount importance to get healthy and vigorous planting stock. Keeping in view the multipurpose uses, rapid increase in growth, demand, capability to enrich surface soil by adding leaf litter and averting soil erosion, it became necessary to investigate the effect on chemical constituents of the soil through poplar cuttings with various doses of fertilizer in temperate conditions of Kashmir, so that results are expected to be useful for the farmers we would like to undertake cultivation of these poplar nurseries.

\section{Materials and Methods}

The study was carried out in Faculty of Forestry, Wadura, Sopore located at Latitude of $34^{\circ}-17^{\circ} \mathrm{N}$ and Longitude $74^{\circ}-3^{\circ} \mathrm{E}$ above an altitude of $1524 \mathrm{~m}$ msl. The mean maximum temperature was recorded in July $\left(30.90^{\circ} \mathrm{C}\right.$ and $30.40^{\circ} \mathrm{C}$ ) and mean minimum in November $\left(-0.35^{\circ} \mathrm{C}\right.$ and $\left.0.16^{\circ} \mathrm{C}\right)$ during the growing season. Rainfall was highest in the month of August $(178.40 \mathrm{~mm}$ ) and September $(193.70 \mathrm{~mm})$ whereas, minimum in November $(17 \mathrm{~mm}$ and $19.60 \mathrm{~mm}$ ), relative humidity was maximum in November $(86.17 \%$ and October 92.29\%) while minimum in July ( $48.13 \%$ and June $44.43 \%$ ). The cuttings were taken from phenotypically superior trees already cultivated in Srinagar district. The fresh cuttings having $20 \mathrm{~cm}$ length and $20 \mathrm{~mm}$ diameter of uniform size were planted/ raised in the second fortnight of February in a well prepared nursery beds of $\left(3.60 \mathrm{~m}^{2}\right)$ with a spacing of $(60 \mathrm{~cm} \times 30 \mathrm{~cm})$ in 
three replicates employing split plot design. The total no. of cuttings planted per species was five hundred forty (540). The study was consisted of 36 treatments having four species Populus nigra $\left(\mathrm{S}_{1}\right)$, P. alba $\left(\mathrm{S}_{2}\right)$, P. ciliata $\left(\mathrm{S}_{3}\right)$ and $P$. balsamifera $\left(\mathrm{S}_{4}\right)$ with three levels of Nitrogen and Phosphorus each @ $\mathrm{N}_{0}, \mathrm{~N}_{75}$, $\mathrm{N}_{150} \mathrm{~kg} \mathrm{ha}^{-1}$ and $\mathrm{P}_{0}, \mathrm{P}_{60}, \mathrm{P}_{120} \mathrm{~kg} \mathrm{ha}^{-1}$ applied into nine combinations viz., $\mathrm{T}_{1}=\mathrm{N}_{0} \mathrm{P}_{0}, \mathrm{~T}_{2}=$ $\mathrm{N}_{0} \mathrm{P}_{60}, \mathrm{~T}_{3}=\mathrm{N}_{0} \mathrm{P}_{120}, \mathrm{~T}_{4}=\mathrm{N}_{75} \mathrm{P}_{0}, \mathrm{~T}_{5}=\mathrm{N}_{75} \mathrm{P}_{60}, \mathrm{~T}_{6}=$ $\mathrm{N}_{75} \mathrm{P}_{120}, \mathrm{~T}_{7}=\mathrm{N}_{150} \mathrm{P}_{0}, \mathrm{~T}_{8}=\mathrm{N}_{150} \mathrm{P}_{60}$, and $\mathrm{T}_{9}=$ $\mathrm{N}_{150} \mathrm{P}_{120}$. The fertilizer was applied in two split doses, first in the second fortnight of April after bud burst in cuttings and second dose in the second fortnight of June at the time of weeding/ hoeing in poplar cutting beds. The nitrogen was supplemented through urea and diamonium phosphate (DAP) while phosphorus was supplemented through single super phosphate (SSP) and DAP. The dosage was determined after calculating the percentage of $\mathrm{N}$ and $\mathrm{P}$ available in different fertilizers.

\section{Collection of soil samples}

The initial soil samples as well as the samples after each growing season were taken randomly from each treatment plot of each species from each replicate at a depth of 0 $20 \mathrm{~cm}$. The soil samples were composited stand wise, dried under shade, crushed and passed through $2 \mathrm{~mm}$ sieve. The sieved samples were analyzed for different chemical properties in the Division of Soil Sciences, SKUAST-K, Shalimar. The methods employed for analysis of various chemical properties are as under:

\section{pH, OC\% and Ecdsm ${ }^{-1}$}

The $\mathrm{pH}$ of soil samples was measured at 20 ${ }^{\circ} \mathrm{C}$ with the help of a digital $\mathrm{pH}$ meter (model $\mathrm{AP} \times 175 \mathrm{E} / \mathrm{C})($ Figure 1). Twenty five gram (25 g) of air dry soil sample was thoroughly mixed with $62.5 \mathrm{ml}$ of distilled water $(1: 2.5$ $\mathrm{w} / \mathrm{v}$ ) and the reading for $\mathrm{pH}$ of the soil samples was taken after 30 minutes. The $\mathrm{pH}$ meter was calibrated before use with Standard pH buffers (pH 4 and pH 7) (Jackson, 1973).

Soil $\mathrm{pH}=\log \frac{1}{\mathrm{H}^{+}}=\log \left(\mathrm{H}^{+}\right)$

$\mathrm{H}+$ is expressed as $\mathrm{g}$ ions $\mathrm{ltr}^{-1}$.

After determining $\mathrm{pH}$, soil suspension was kept overnight in undisturbed condition and EC was measured by conductivity meter (Digital CD-601) (Figure 2) (Jackson, 1973). Organic carbon (OC) was estimated by wet digestion method of Walkley and Black (1934). The known weight of soil was treated with excess standard $\mathrm{K}_{2} \mathrm{Cr}_{2} \mathrm{O}_{7}$ in presence of concentrated Sulfuric acid. The excess $\mathrm{K}_{2} \mathrm{Cr}_{2} \mathrm{O}_{7}$ not reduced by the organic matter of the soil, was determined by back titration with standard ferrous ammonium sulphate using diphenylamine indicator. Organic carbon percentage was calculated by using the following formula:

$\begin{array}{ll}\begin{array}{l}\text { Soil organic } \\ \text { carbon }(\mathrm{SOC})\end{array} & \begin{array}{l}10 \\ =\end{array} \\ \mathrm{B}\end{array} \times \frac{0.003 \times 100}{\begin{array}{l}\text { Weight of } \\ \text { soil sample }\end{array}} \times$

Where,

$\mathrm{B}=$ Volume of titrant used for blank.

$\mathrm{T}=$ Volume of titrant used for sample.

Since it is assumed that organic carbon recovery by this method is only $77 \%$, the values obtained were multiplied by a correction factor of 1.3.

\section{Nitrogen $\left(\mathrm{kg} \mathrm{ha}^{-1}\right)$}

Following procedure as described by Subbiah and Asija (1956) was used to determine 
Nitrogen $\left(\mathrm{kg} \mathrm{ha}^{-1}\right)$ (Figure 3).

\begin{tabular}{ll} 
Available & $($ sample $\quad$ titer-blank \\
nitrogen $\left(\mathrm{kg} \mathrm{ha}^{-1}\right)$ & titre $) 0.02 \times 14 \times 2.24 \times$ \\
$=$ & $10^{6}$ \\
\cline { 2 - 2 }$=$ & Weight of soil sample $(\mathrm{g})$ \\
& $\times 1000$
\end{tabular}

\section{Phosphorous and Potassium $\left(\mathrm{kg} \mathrm{ha}^{-1}\right)$}

Available phosphorus was extracted by using $0.5 \mathrm{~N} \mathrm{NaHCO}_{3}$ at $8.5 \mathrm{pH}$ and colour developed by using ammonium molybdate and stannous chloride (Figure 4). The transmittance was measured with the help of spectrophotometer at $660 \mathrm{~nm}$ wave length (Olsen et al., 1954). The concentrations of available phosphorus were calculated by reference to a calibration graph plotted from the standard phosphorus $\left(\mathrm{KH}_{2} \mathrm{PO}_{4}\right)$ solution. Blanks were run in the same manner without soil. Potassium was estimated by Neutral normal ammonium acetate solution was used as extractant for available potassium from soil and determination was carried out on Digital Flame Photometer (Model CL 22D) (Figure 4) (Jackson, 1973).

\section{Exchangeable Calcium and Magnesium}

Exchangeable $\mathrm{Ca}^{+2}$ and $\mathrm{Mg}^{+2}$ were determined in $\mathrm{NH}_{4} \mathrm{OAC}$ leachate with EDTA titration method using ammonium purpurate and eriochrome black (T) indicator as described by (Jackson, 1973) by AASFM (Atomic absorption spectrophotometer) (Figure 3).

\section{Results and Discussion}

\section{Primary and Secondary Nutrients}

The initial status of soil with respect to NPK was found in the range of medium with $380.24 \mathrm{~kg} \mathrm{ha}^{-1}, 20.19 \mathrm{~kg} \mathrm{ha}^{-1}$ and $221.19 \mathrm{~kg}$ $\mathrm{ha}^{-1}$ (Table 1) and sufficient in $\mathrm{Ca}(869.46$ ppm) and $\mathrm{Mg}$ (276.09 ppm) (Table 2), respectively. The results obtained showed that during the first year the concentration of all the nutrients declined from the initial values with maximum decline in $\mathrm{T}_{1}$ (control) and minimum decline at highest level of fertilizer dose either alone or in combination. However, in the second growing year there was substantial increase of all the nutrients with the increase in fertilizer dose. The maximum increase was recorded at $\mathrm{T}_{6}, \mathrm{~T}_{8}$ and $\mathrm{T}_{9}$ which were found at par with each other but differ significantly over all the treatments. Decrease in first year is due to the reason that short rotation forest species grow rapidly and bind a great amount of nutrients in their biomass and also the losses due to the leaching, denitrification and amonification is high because urea takes some days for the hydrolysis of amide form and its conversion to ammonical form which gets converted into nitrate slowly and becomes available for plant use within a few days. While as in second growing year the increase in nutrients was probably due to leaf litter addition and subsequent decomposition and mineralization. Moscatelli et al., (2008) reported that nitrogen fertilization did not modify soil capacity to accumulate organic matter although, a positive variation was observed at the beginning of the study.

Significant changes were seen in the soil properties after second growing season. Savill (2004) who reported that the leaves of the deciduous broad leaved trees retain the major nutrient bases when they drop in the autumn. Thus, the litter under these forests is not as acidic as under evergreen forests. Also, the autumn leaf fall provides abundant and rich organic matter which begins to decay rapidly in following spring. While, as $\mathrm{P}$ concentration increases due to the addition of litter fall which results into formation of polyhumic substances and coating of $\mathrm{Al}$ and $\mathrm{Fe}$ ions, thus the higher content of $\mathrm{P}$ in soil in second year 
may be attributed to the higher content of organic matter in the soil which prevents the fixation of $\mathrm{P}$ ions, which is line with the findings of Savill (2004). Ghosh and Kothandaraman (1996) showed that organic P fraction contributed 23.9 to 46.9 per cent $\mathrm{P}$ with their amount being high in higher organic carbon and gradually decreased with decrease in organic carbon content of soil. It is evident from the results (Table 3 ) that the available $\mathrm{K}$ in the soil for first and second year was found in the range of medium due to the reason that $\mathrm{K}$ is always in the exchangeable form in the soil. The $\mathrm{Ca}$ and $\mathrm{Mg}$ in the soil was recorded in the range of sufficient for both the years but maximum was found in treatment $T_{9}$ and minimum in $T_{1}$ but in $1^{\text {st }}$ year it decreases but increased subsequently in the $2^{\text {nd }}$ year. It may be due to the reason that $\mathrm{N}$ and $\mathrm{P}$ have synergetic effect for $\mathrm{Ca}$ and $\mathrm{Mg}$ which increases the percentage of nutrients in plant and maximum percentage is returned back at the time of abscised leaves into the soil which increased the nutrient concentration after decomposition.

These results are in line with the findings of Srivastava et al., (1972) who reported that in moist deciduous forests leaf litter returns adds substantial amount of various nutrient elements to the soil. Baker and Blackman (1977) who revealed that there was 43.5, 4.7, $34.7 \mathrm{~kg} \mathrm{ha}{ }^{-1}$ accumulation of $\mathrm{N}, \mathrm{P}, \mathrm{K}$ respectively just before the litter fall and approximately 26, 33 and $28 \%$ of these elements fell with abscised leaves. Thus from the above results it is clear that nutrient status of the soil is very important in short rotation forestry which is in conformity with the observations made by Hytonen (1996) who reported that besides climatic conditions different soil properties effect biomass production. In particular the nutrient status of the soil is very important in short rotation forestry as they grow rapidly and bind a great amount of nutrients in their biomass.

\section{Soil pH and Organic carbon}

The studies conducted on soil analysis revealed that the average soil $\mathrm{pH}$ decreased with the increase in fertilizer doses either individually or in combination of $\mathrm{N}$ and $\mathrm{P}$. The maximum decrease was recorded at $\mathrm{T}_{9}$ $(6.28,6.26)$ and minimum at $\mathrm{T}_{1}(6.34,6.33)$ from its initial values 6.36 in two consecutive years, respectively. The organic carbon increased from $\mathrm{T}_{1}$ to $\mathrm{T}_{9}$ and maximum $\mathrm{OC} \%$ was recorded at $\mathrm{T}_{9}(1.337,1.495)$ and minimum at $\mathrm{T}_{1}(1.290,1.305)$ in two years, respectively. The change in $\mathrm{pH}$ from initial in two growing years recorded was not as much, however after change the $\mathrm{pH}$ was found suitable for the growth of poplar species. The increase in (SOC) soil organic carbon per cent compared to their initial values 1.252 increases during the two growing years.

The increase in SOC and decrease in $\mathrm{pH}$ was due to the reason that the growth of the poplar species was recorded maximum with the increase in level of fertilizer doses than control which was believed to be due to the effect of litter addition. Leaves of the deciduous trees decomposes readily, which increases the OC\% and during decomposition of leaves the acids were released due to microbial oxidation of leaves and hydrolysis of urea and nitrification of products which consequently decreased the soil $\mathrm{pH}$. These results are in agreement with the findings of Arsova (1995) reported decrease in soil pH with increase in fertilizer level while studying the effect of fertilizer application Savill (2004) who reported that the leaves of the deciduous broad leaved trees retain the major nutrient bases when they drop in the autumn. Thus, the litter under these forests is not as acidic as under evergreen forests. Also the autumn leaf fall provides abundant and rich organic matter which begins to decay rapidly in following spring. While as, $\mathrm{pH}$ obtained was suitable for the growth of poplar species 
under test is in line with the findings of Sennerby and Forsse (1990) who reported that the suitable $\mathrm{pH}$ values of the soil for willow cultivar is 5.5-6.5 and it is also reported by Cannell, (2004) that poplar and willows grow best on mildly acidic pH 6.0-7.0.

\section{Nitrogen $\left(\mathrm{kg} \mathrm{ha}^{-1}\right)$}

Take $5 \mathrm{~g}$ soil in Kjeldhal tube<smiles>[AlH2]</smiles>

Add a little distilled water and $25 \mathrm{ml} \mathrm{KMnO}_{4}$

$\downarrow$

Place a conical flask $(250 \mathrm{ml})$ containing $25 \mathrm{ml}$ boric acid solution in such a way that the end of condenser tube dips into the boric acid solution.

$\downarrow$

Connect the Kjeldhal tube to the distillation assembly and add about $25 \mathrm{ml}$ sodium hydroxide

$(2.5 \%)$

$\downarrow$

Set the process time 15-18 minutes (about $150 \mathrm{ml}$ distillation is collected in receiving flask) and Test with red litmus paper to ensure total distillation $\downarrow$

Titrate the distillate with standard $0.02 \mathrm{~N} \mathrm{H}_{2} \mathrm{SO}_{4}$ to wine red end point Run a blank in the same way

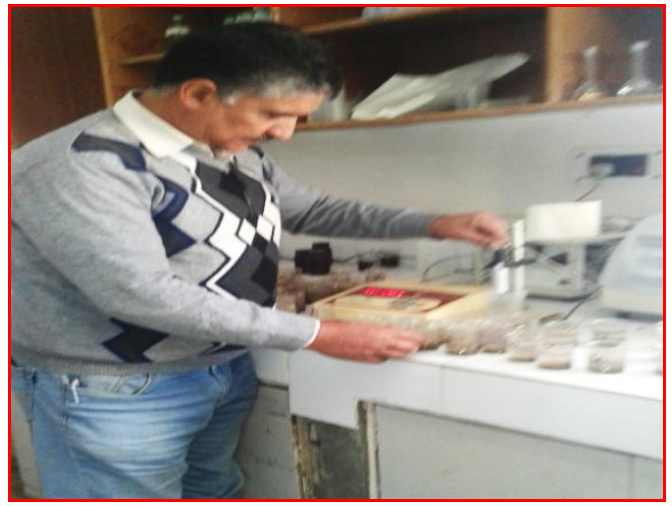

Figure 1: $\mathrm{pH}$ analysis

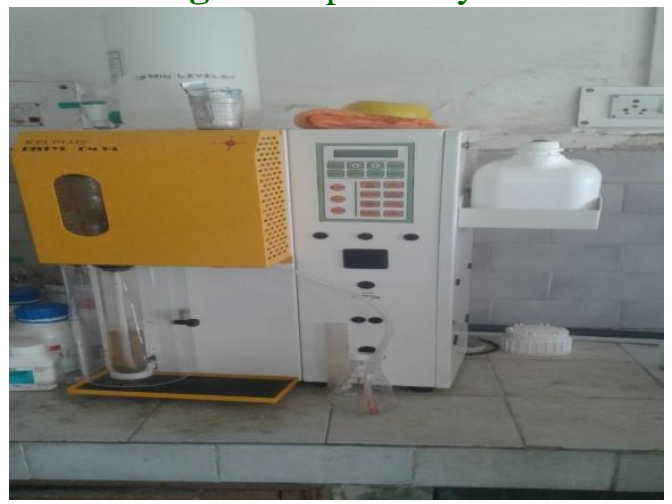

Figure 3: Soil nitrogen analysis

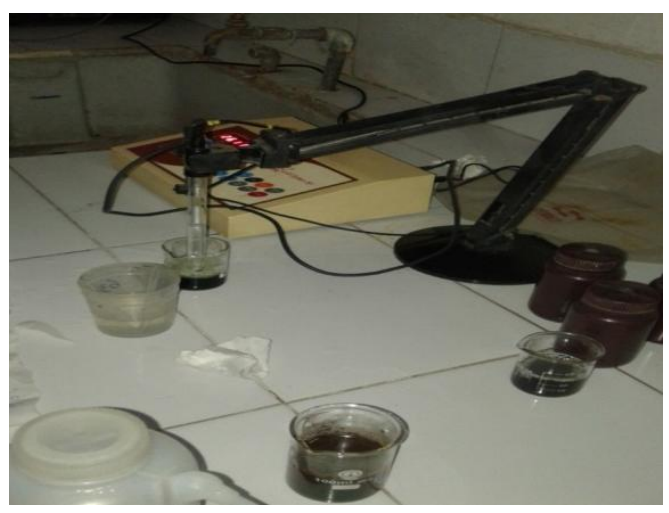

Figure 2: $\mathrm{EC} \mathrm{dsm}^{-1}$ analysis

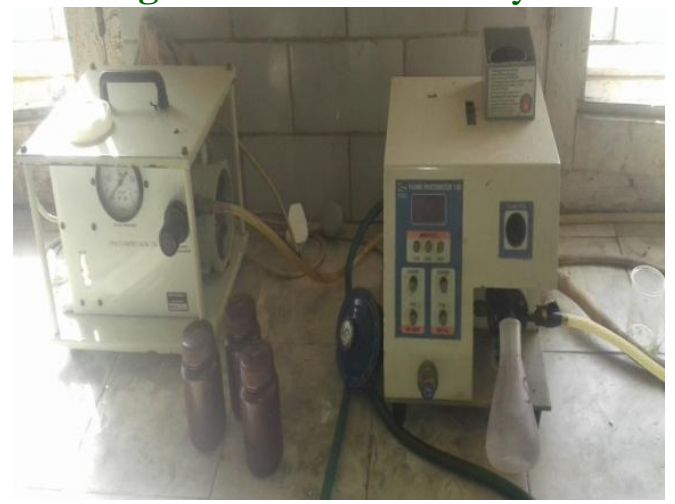

Figure 4: Soil P, K, Ca \& Mg analysis 
Table.1 Effect of various fertilizer dosages on soil properties in nursery

\begin{tabular}{|c|c|c|c|c|c|c|}
\hline Initial value & \multicolumn{2}{|c|}{$380.24\left(\mathrm{~N} \mathrm{~kg} \mathrm{ha}^{-1}\right)$} & \multicolumn{2}{|c|}{$20.19\left(\mathrm{P} \mathrm{kg} \mathrm{ha}^{-1}\right)$} & \multicolumn{2}{|c|}{$221.14\left(\mathrm{~K} \mathrm{~kg} \mathrm{ha}^{-1}\right)$} \\
\hline Treatments & $1^{\text {st }}$ year & $2^{\text {nd }}$ year & $1^{\text {st }}$ year & $2^{\text {nd }}$ year & $1^{\text {st }}$ year & $2^{\text {nd }}$ year \\
\hline $\mathbf{N}_{0} P_{0}$ (control) & 373.00 & 374.48 & 18.62 & 19.09 & 217.09 & 218.37 \\
\hline $\mathrm{N}_{0} P_{1}\left(0,60 \mathrm{~kg} \mathrm{ha}^{-1}\right)$ & 375.21 & 378.23 & 19.39 & 20.29 & 217.68 & 218.97 \\
\hline $\mathrm{N}_{0} P_{2}\left(0,120 \mathrm{~kg} \mathrm{ha}^{-1}\right)$ & 376.21 & 379.24 & 19.70 & 20.74 & 217.85 & 219.14 \\
\hline$N_{1} P_{0}\left(75,0 \mathrm{~kg} \mathrm{ha}^{-1}\right)$ & 377.75 & 381.51 & 19.05 & 19.96 & 218.79 & 220.08 \\
\hline$N_{1} P_{1}\left(75,60 \mathrm{~kg} \mathrm{ha}^{-1}\right)$ & 378.31 & 382.34 & 19.95 & 21.14 & 219.21 & 220.50 \\
\hline $\begin{array}{l}N_{1} P_{2}(75,120 \mathrm{~kg} \mathrm{ha} \\
1_{)}\end{array}$ & 379.63 & 383.34 & 20.45 & 21.44 & 219.50 & 220.79 \\
\hline $\mathrm{N}_{2} \mathbf{P}_{0}\left(150 \mathrm{~kg} \mathrm{ha}^{-1}\right)$ & 377.96 & 381.69 & 19.13 & 20.09 & 218.82 & 220.11 \\
\hline $\begin{array}{l}\mathrm{N}_{2} \mathrm{P}_{1}(150,60 \mathrm{~kg} \text { ha } \\
\left.{ }^{\prime}\right)\end{array}$ & 379.69 & 383.47 & 20.50 & 21.66 & 219.54 & 220.83 \\
\hline $\begin{array}{l}\mathbf{N}_{2} P_{2}(150,120 \mathrm{~kg} \mathrm{ha} \\
\end{array}$ & 379.73 & 383.51 & 20.53 & 21.68 & 219.61 & 220.90 \\
\hline CDP $<0.05$ & 0.40 & 0.80 & 0.14 & 0.24 & 0.14 & 0.19 \\
\hline
\end{tabular}

Table.2 Effect of various fertilizer dosages on soil properties in nursery

\begin{tabular}{|c|c|c|c|c|c|c|c|c|c|c|}
\hline \multirow{2}{*}{$\begin{array}{l}\text { Initial value } \\
\text { Treatments }\end{array}$} & \multicolumn{2}{|c|}{$\begin{array}{l}869.46 \\
\text { ppm })\end{array}$} & \multicolumn{2}{|c|}{$\begin{array}{l}\begin{array}{l}276.09 \\
\text { ppm })\end{array} \quad \text { (Mg } \\
\end{array}$} & \multicolumn{2}{|c|}{$6.360(\mathrm{pH})$} & \multicolumn{2}{|c|}{$1.252(\mathrm{OC} \%)$} & \multicolumn{2}{|c|}{$\underset{1}{0.156}\left(\mathrm{Ec} \mathrm{dsm}^{-}\right.$} \\
\hline & $\begin{array}{l}1^{\text {st }} \\
\text { year }\end{array}$ & $2^{\text {nd }}$ year & $\begin{array}{l}1^{\text {st }} \\
\text { year }\end{array}$ & $2^{\text {nd }}$ year & $\begin{array}{l}1^{\text {st }} \\
\text { year }\end{array}$ & $2^{\text {nd }}$ year & $\begin{array}{l}1^{\text {st }} \\
\text { year }\end{array}$ & $2^{\text {nd }}$ year & $\begin{array}{l}1^{\text {st }} \\
\text { year }\end{array}$ & $2^{\text {nd }}$ year \\
\hline $\begin{array}{l}\mathbf{N}_{\mathbf{0}} \mathbf{P}_{\mathbf{0}} \\
\text { (control) }\end{array}$ & 835.81 & 840.45 & 258.32 & 258.93 & 6.340 & 6.331 & 1.290 & 1.305 & 0.157 & 0.160 \\
\hline 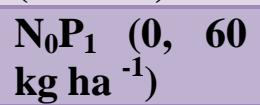 & 837.38 & 842.08 & 260.48 & 261.08 & 6.332 & 6.315 & 1.297 & 1.341 & 0.158 & 0.163 \\
\hline $\begin{array}{l}\mathbf{N}_{0} \mathbf{P}_{2}(\mathbf{0}, 120 \\
\left.\operatorname{kg~ha}^{-1}\right)\end{array}$ & 838.95 & 843.65 & 260.90 & 261.51 & 6.329 & 6.314 & 1.305 & 1.376 & 0.159 & 0.164 \\
\hline 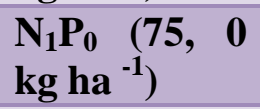 & 840.52 & 845.23 & 259.28 & 259.89 & 6.317 & 6.297 & 1.316 & 1.411 & 0.161 & 0.166 \\
\hline $\begin{array}{l}N_{1} P_{1}(75,60 \\
\left.k g ~ h a^{-1}\right)\end{array}$ & 842.45 & 847.20 & 261.75 & 262.36 & 6.305 & 6.287 & 1.326 & 1.449 & 0.163 & 0.170 \\
\hline $\begin{array}{l}\mathrm{N}_{1} \mathbf{P}_{2}(75,120 \\
\left.\mathrm{kg} \mathrm{ha}^{-1}\right)\end{array}$ & 845.24 & 849.51 & 262.62 & 263.27 & 6.294 & 6.266 & 1.335 & 1.484 & 0.164 & 0.175 \\
\hline $\begin{array}{l}\mathbf{N}_{2} \mathbf{P}_{0}(150 \mathrm{~kg} \\
\left.\mathrm{ha}^{-1}\right)\end{array}$ & 840.72 & 845.34 & 259.41 & 260.04 & 6.291 & 6.289 & 1.315 & 1.415 & 0.160 & 0.166 \\
\hline $\begin{array}{l}N_{2} P_{1}(150,60 \\
\left.\operatorname{kg~ha}^{-1}\right)\end{array}$ & 845.46 & 849.86 & 262.68 & 263.36 & 6.290 & 6.263 & 1.290 & 1.305 & 0.164 & 0.175 \\
\hline $\begin{array}{l}\mathbf{N}_{2} \mathbf{P}_{2}(150,120 \\
\left.\operatorname{kg~ha}^{-1}\right)\end{array}$ & 845.88 & 850.08 & 262.87 & 263.56 & 6.289 & 6.260 & 1.297 & 1.341 & 0.164 & 0.176 \\
\hline $\mathrm{CDP}<0.05$ & 1.41 & 1.54 & 0.61 & 0.62 & 0.004 & 0.008 & 0.004 & 0.031 & N.S & N.S \\
\hline
\end{tabular}


Table.3 Effect of various Poplar species on soil properties in nursery

\begin{tabular}{|c|c|c|c|c|c|c|}
\hline \multirow[t]{2}{*}{ Treatments } & \multicolumn{2}{|c|}{$\mathrm{N} \mathrm{kg} \mathrm{ha}^{-1}$} & \multicolumn{2}{|c|}{ P kg ha $^{-1}$} & \multicolumn{2}{|c|}{$\mathrm{K} \mathrm{kg} \mathrm{ha}^{-1}$} \\
\hline & $1^{\text {st }}$ year & $2^{\text {nd }}$ year & $1^{\text {st }}$ year & $2^{\text {nd }}$ year & $1^{\text {st }}$ year & $2^{\text {nd }}$ year \\
\hline$S_{1}(P$. nigra $)$ & 377.53 & 380.99 & 19.69 & 20.76 & 218.61 & 220.12 \\
\hline $\mathbf{S}_{2}(P$. ciliata $)$ & 377.72 & 380.57 & 19.72 & 20.57 & 218.81 & 219.31 \\
\hline $\mathrm{S}_{3}(P$. alba $)$ & 377.76 & 380.41 & 19.73 & 20.54 & 218.92 & 219.24 \\
\hline $\mathrm{S}_{4}(P$. balsamifera $)$ & 377.00 & 381.50 & 19.67 & 20.83 & 218.37 & 221.20 \\
\hline CD $P<0.05$ & 0.13 & 0.15 & N.S & 0.17 & 0.22 & 0.34 \\
\hline
\end{tabular}

Table.4 Effect of various Poplar species on soil properties in nursery

\begin{tabular}{|c|c|c|c|c|c|c|c|c|c|c|}
\hline \multirow[t]{2}{*}{ Treatments } & \multicolumn{2}{|c|}{ Ca ppm } & \multicolumn{2}{|c|}{ Mg ppm } & \multicolumn{2}{|l|}{ pH } & \multicolumn{2}{|l|}{ OC\% } & \multicolumn{2}{|c|}{ Ec dsm ${ }^{-1}$} \\
\hline & $\begin{array}{l}1^{\text {st }} \\
\text { year }\end{array}$ & $2^{\text {nd }}$ year & $\begin{array}{l}1^{\text {st }} \\
\text { year }\end{array}$ & $2^{\text {nd }}$ year & $\begin{array}{l}1^{\text {st }} \\
\text { year }\end{array}$ & $2^{\text {nd }}$ year & $\begin{array}{l}1^{\text {st }} \\
\text { year }\end{array}$ & $2^{\text {nd }}$ year & $\begin{array}{l}1^{\text {st }} \\
\text { year }\end{array}$ & $2^{\text {nd }}$ year \\
\hline$S_{1}(P$. nigra $)$ & 840.38 & 846.65 & 260.81 & 261.62 & 6.311 & 6.290 & 1.327 & 1.423 & 0.161 & 0.172 \\
\hline $\begin{array}{ll}\mathbf{S}_{2} & (\boldsymbol{P} . \\
\text { ciliata })\end{array}$ & 842.92 & 845.19 & 261.05 & 261.40 & 6.312 & 6.296 & 1.295 & 1.397 & 0.161 & 0.164 \\
\hline$S_{3}(P, a l b a)$ & 843.85 & 844.55 & 261.12 & 261.36 & 6.313 & 6.306 & 1.294 & 1.394 & 0.160 & 0.163 \\
\hline $\begin{array}{lr}\mathrm{S}_{4} & (P . \\
\text { balsamifera })\end{array}$ & 838.36 & 847.35 & 260.72 & 261.85 & 6.303 & 6.274 & 1.353 & 1.460 & 0.161 & 0.174 \\
\hline CD $P<0.05$ & 0.18 & 0.19 & 0.06 & 0.02 & 0.005 & 0.009 & 0.006 & 0.018 & N.S & N.S \\
\hline
\end{tabular}

\section{Electrical conductivity}

The ECdsm ${ }^{-1}$ increases with the increase in fertilizer dose either individually or in combination of $\mathrm{N}$ and $\mathrm{P}$ application but it was found non-significant. The interaction among the fertilizer and among the species was also found non-significant. The electrical conductivity was maximum at $\mathrm{T}_{9}(0.164$, $\left.0.176 \mathrm{dsm}^{-1}\right)$ and minimum at $\mathrm{T}_{1}(0.157,0.160$ $\mathrm{dsm}^{-1}$ ) which was best for the growth and development of the family Salicaceae. These results are in agreement with the findings of Crouch and Honeyman (1986) who conducted experiment on 29 Salix species and cultivars of $P$. nigra var. italic grown in soil with salt solutions of electrical conductivity of $0.05,1$, 2 and $4 \mathrm{dsm}^{-1}$ and reported that the least tolerant were Salix piperi, Salix purpurea cultivar irtle and Salix seringerna and $P$. nigra var. italic were tolerant than other species. In our study among the species the maximum mean electrical conductivity was recorded in $P$. balsamifera $(1.353,1.381)$ followed by $P$. nigra (1.327, 1.349), $P$. Ciliata $(1.295,1.307)$ and P. alba (1.294, 1.305) $\mathrm{dsm}^{-1}$ (Table 4). It is due to the reason that different species have different genetic makeup with the result different species can tolerate different electrical conductivity. So our results collaborates with above findings that among the species the most tolerant was $P$. balsamifera followed by $P$. nigra, $P$. Ciliata and P. alba.

\section{Conclusion}

In order to produce high-quality nursery plants of $P$. nigra, $P$. ciliata, $P$. alba and $P$. balsamifera, cultivation of cuttings from phenotypically superior trees is a must. Treatment of the cuttings with a combination of $\mathrm{N}\left(75 \mathrm{~kg} \mathrm{ha}^{-1}\right)$ and $\mathrm{P}\left(120 \mathrm{~kg} \mathrm{ha}^{-1}\right)$ is the precondition to achieve tremendous survival 
and growth of the nursery plants which is generally poorly understood and poorly practiced. Further, the propagation of nursery plants with these treatments improves soil properties overwhelmingly as depicted by the findings of the study.

\section{Acknowledgements}

This research was conducted under the aegis of Faculty of Forestry, SKUAST-K Shalimar, which is gratefully acknowledged. Sincere thanks are also due to SKUAST-K for the assistance to carry out this work.

\section{References}

Arsova, A. 1995. Effect of fertilizer application and soil $\mathrm{pH}$ on the acidic and sorption properties of maize leaves and stems. Bulgarian Journal of Plant Physiology, 21(1): 52-57.

Baker, J.B. and Blackman, B.G. 1977. Biomass and nutrient accumulation in a cottonwood plantation-the first growing season. Soil Science Society American Journal, 41: 632-636.

Bhardwaj, S.D, Panwar, P. and Gautam, S. 2001. Biomass Production Potential and Nutrient Dynamics of Populus deltoides under high density Plantations. Indian Forester, 127(2): 144-153.

Cannell, M.G.R. 2004. Short rotation forestry for biomass production In: Encyclopedia of Forest-Sciences (Eds. B. Jaffery, Ejulani, Y. A. Jhon), 2: 874-875.

Crouch, R.J. and Honeyman, M.N. 1986. The relative salt tolerance of willow cuttings. Journal of Soil Conservation, New-SouthWales, 42(2): 103-104.

Dhiman, R.C. 2012. Status of poplar culture in India. Forestry Bulletin, 12(1): 15-32.

Gangoo, S.A., Masoodi, T.H., Shah, M. and Islam, M.A. 2015. Management of exotic poplars for production of quality timber and reducing cotton menace in Kashmir. The Indian Forester, 141(5): 514-519.

Gangoo, S.A., Mir, M.A., Khan, A.A. and Gul-
Zaffar. 2011. Study of variability in the cultivated clones of Populus nigra Linn. (black poplar) of Kashmir valley. Indian Forester, 137(6): 704-717.

Ghosh, T.J. and Kothandaraman, G.V. 1996. Organic phosphorus fractions in some soils of Tamil Nadu in relation to organic carbon status of soil. Journal of Indian Society and Soil Science, 44(2): 324-325.

Hytonen, J. 1996. Biomass production and nutrition of short rotation plantations. The Finnish Forest Research Institute Research paper, pp. 556-561.

Islam, M.A., Masoodi, T.H., Gangoo, S.A., Sofi, P.A., Bhat, G.M., Wani, A.A., Gatoo, A.A., Singh, A. and Malik, A.R. 2015. Perceptions, attitudes and preferences in agroforestry among rural societies of Kashmir, India. Journal of Applied and Natural Science, 7(2): 976983.

Islam, M.A. 2016. Management of poplar cotton menace in Kashmir valley. Van Sangyan, 3(3): 15-17.

Islam, M.A., Sofi, P.A., Bhat, G.M., Wani, A.A., Gatoo, A.A., Singh, A. and Malik, A.R. 2016. Prediction of agroforestry adoption among farming communities of Kashmir valley, India: a logistic regression approach. Journal of Applied and Natural Science, 8(4): 2133-2140.

Jackson, M.L. 1973. Soil chemical analysis. Prentice Hall of India Pvt. Ltd., New Delhi.

Kaushik, A., Negi, R., Barthwal, S. and Singh, Y.P. 2012. Mapping Research on Poplar (Populus spp.) in 'Forest Science Database', Forestry Bulletin, 12(1): 151156.

Kumar, D. and Singh, N.B. 2012. Status of Poplar Introduction in India. Forestry Bulletin, 12(1): 9-14.

Masoodi, T.H., Ahmad, H., Gangoo, S.A., Sofi, P.A., Bhat, M.A. and Islam, M.A. 2014. Ecological occurrence of Himalayan Poplar (Populus ciliata Wallich. Ex. Royle.) and its nursery evaluation under temperate conditions of Kashmir. The Bioscan, 9(2): 585-588. 
Moscatelli, M.C., Lagomarsino, A.P.D. and Grego, S. 2008. Short and medium term contrasting effects of nitrogen fertilization on $\mathrm{C}$ and $\mathrm{N}$ cycling in a poplar plantation. Forest Ecology and Management, 255: 447-454.

Olsen, S.R., Cole, W., Watanable, F.S. and Dean, L.A. 1954. Estimation of available phosphorus in soils by extraction wit sodium bi-carbonate In: Methods of soil analysis. (Ed. C. A. Black). Madison. American Society Agronomy, 10: 44-46.

Puri, S. 1993. Mass culturing of trees by vegetative means: Techniques and Constraints. In: Nursery Technology for Agro-forestry: Applications in Arid and Semi-Arid regions (Eds. S. Puri and P. K. Khosla), Oxford and IBH Publishing CO. Pvt. Ltd; New Delhi pp. 125-136.

Rather, T.A., Gangoo, S.A., Ahmad, S.B., Islam, M.A., Bhat, G.M., Sofi, P.A. and Mir, A.A. 2017. Economics of entire transplants (ETPs) production of poplar species through cuttings under various fertilization regimes. Chemical Science Review and Letters, 6(22): 971-977.

Rather, T.A., Gangoo, S.A., Islam, M.A., Sofi, P.A., Bhat, G.M. and Mir, A.A. 2018. Nitrogen and phosphorus use efficiency of poplar species under different fertilization levels in Kashmir. Journal of Pharmacognosy and Phytochemistry, 7(3): 1495-1498.

Savill, P.S. 2004. Temperate broad leaved deciduous forest. In: Encyclopedia of Forest Sciences (Eds. B. Jaffery, E. Julain and Y. A. Jhon), 3: 1398-1403.

Sennerby-Forsse, L. and Johansson, H. 1990. Energiskog Handboki Praktisk Odling.
Uppsala Solar pp. 45.

Singh, H. and Mavi, H.K. 2016. Economic analysis of poplar based agroforestry system under riparian wet land conditions of Punjab. Indian Journal of Economics and Development, 12(1): 191-196.

Sofi, P.A., Bhat, S.A., Masoodi, T.H., Islam, M.A., Bhat, G.M. and Malik, A.R. 2016. Propagation of Himalayan maple (Acer caesium Wall.) through seed and softwood cuttings. Journal of Applied and Natural Science, 8(3): 1235-1240.

Sofi, P.A., Chopan, J.A., Islam, M.A., Bhat, G.M., Malik, A.R. and Rather, T.A. 2018. Nitrogen Use Efficiency, Nutritive Value of Leaves and Survival of Moso Bamboo (Phyllostachys pubescence) Seedlings under the Influence of N-Fertigation. Chemical Science Review and Letters, 7(26): 673-679.

Srivastava, P.B.L., Kaul, O.N. and Mathur, H. 1972. Seasonal variation of nutrients and their return through leaf litter in some plantation ecosystems. Proceeding Symp. On Manmade Forests in India Society of Indian Forester, Dehradun.

Subbiah, B.V. and Asija, G.L. 1956. A rapid procedure for estimation of available nitrogen in soils. Current Science, 25: 259-260.

Tewari. D.N. 1993. Poplar. Dehradun, Surya Publications pp. 321.

Walkley, A. and Black, C.A. 1934. An examination of the Degtijareff method for determination of soil organic matter and proposed modification of the chromic acid titration method. Soil Science, 37: 29-38.

\section{How to cite this article:}

Rather, T.A., S.A. Gangoo, M.A. Islam, P.A. Sofi, G.M. Bhat and Mir, A.A. 2019. Effect of Fertilization on Soil Properties under Different Poplar Species in Nursery under Temperate Conditions of Kashmir. Int.J.Curr.Microbiol.App.Sci. 8(07): 2754-2765. doi: https://doi.org/10.20546/ijcmas.2019.807.337 